\title{
AMALAN YANG TIDAK DIPERHATIKAN KAUM SUFI
}

\author{
Muhammad Khoiri \\ mkhoiri8809@gmail.com \\ Dosen Ilmu Tasawuf IAI Pangeran Diponegoro Nganjuk
}

\begin{abstract}
Abstrak
Umat Islam umumnya dan kaum sufi khususnya berpedoman kepada al-Qur'an dan sunnah nabi. Namun secara umum mereka hanya mementingkan diri sendiri dengan meperbanyak dzikir, dan terkesan kurang kurang memperhatikan kemajuan umat Islam secara umum. Umat Islam saat ini tertinggal jauh akibat melupakan amalan yang seharusnya diprioritaskan oleh umat Islam itu sendiri. Artikel ini membahas tentang amalan yang dilupakan oleh kaum sufi, padahal seharusnya diutamakan. Kesimpulan dari artikel ini adalah kaum sufi lebih banyak menghabiskan waktunya untuk berdzikir dan kurang peka terhadap kemajuan umat Islam. Padahal kemajuan umat Islam itu bisa diraih dengan mengamalkan perintah Allah yang pertama kali turun yaitu dengan membaca dan menulis, bukan berdzikir atau shalat.
\end{abstract}

Kata kunci: tarekat, baca-tulis.

\section{Pendahuluan}

Sufi adalah orang yang mendekatkan diri kepada Allah swt. dengan cara dan selera masing-masing berdasarkan perintah Allah dan rasul-Nya. Bagi yang 'hobi' pembacaan al-Qur'an, mereka akan mengikuti majlis istima' al-Qur'an. Sedangkan bagi orang yang 'hobi' dengan shalawat akan memilih menjadi 'Syaikher mania'. Sedangkan tarekat adalah jalan yang dipilih oleh kaum sufi untuk mendekatkan diri kepada Allah berdasarkan petunjuk syari'at dan bimbingan mursyid.

Tujuan dari seorang sufi dan orang yang ikut tarekat adalah sama, yaitu sama-sama ingin mendekatkan diri kepada Allah. Rata-rata orang yang ikut tarekat memiliki amalan tertentu yang diaplikasikan dalam bentuk dzikir. Ada yang membaca là ilaha illa Allăh dengan bilangan tertentu. Ada yang membcara Allăh, Allăh dengan bilangan tertentu, ada pula yang berdzikir secara keras dan sirri.

Spiritualis, vol. 4, no. 2, September 2018

ISSN: 2442-5907|211 
Menurut Artur J. Arberry yang dikutip oleh Ris'an Rusli menyatakan bahwa tarekat Islam secara institusional baru berdiri pada abad ke-6 dan ke-7 Hijriyah. Hal itu dapat ditemukan dengan berdirinya tarekat Yasafiyah yang didirikan oleh Ahmad Yasafi pada tahun 562 H/1169 M. Tarekat Khawajaqiwizah yang dinisbatkan kepada 'Abd alKhāliq al-Ghaznawi (w. 612 H/1220 M). Tarekat Qadiriyah yang didirikan oleh Shaikh 'Abd al-Qādir al-Jaylāni ${ }^{1}$ (w. $561 \mathrm{H}$ ).

Jika melihat tahun berdirinya tarekat secara kelembagaan ini, dapat diketahui bahwa mereka berdiri pada abad ke-6 dan ke-7 Hijriyah. Secara umum, penekanan orang yang mengikuti tarekat adalah agar mereka mengamalkan 'ubudìyah, secara teratur dan sungguh-sungguh. Baik berupa shalat, berdzikir, dan sebagainya. Padahal perintah alQur'an pertama bukanlah shalat, bukan dzikir dan bukan 'ubudiyah yang lain. Akan tetapi al-Qur'an turun pertama kali justru memerintahkan untuk membaca dan menulis. Sayangnya, perintah pertama ini kurang diperhatikan oleh umat Islam, termasuk kaum sufi.

\section{Keseimbangan Dunyawiyah dan Ukrawiyah}

Penulis tidak sedikitpun ingin mengkritik tarekat tertentu, akan tetapi hanya ingin mempertimbangkan bahwa jika umat Islam seluruhnya disibukkan oleh aspek ubudiyah mạ̣dah seperti shalat, dzikir, puasa dan sebagainya, lalu bagaimana dengan urusan dunyawijah mereka?. Tentu kedua-duanya harus seimbang. Bukankah pesan alQur'an secara umum menjelaskan bahwa urusan dunia dan akhirat harus seimbang. Hal ini sesuai dengan jumlah kata dunya di dalam alQur'an disebutkan sebanyak 115 kali. Sedangkan kata akbirah juga disebutkan sebanyak 115 kali. $^{2}$

Dengan demikian kedua-duanya harus balance. Seorang orientalis bernama Artur J. Arberry mengkritik para sufistik Islam dengan menyatakan bahwa "tarekat di banyak tempat tetap menarik masyarakat

\footnotetext{
1 Ris'an Rusli, Tasawnf dan Tarekat: Studi Perbandingan Pengalaman Sufi (Jakarta: Raja Grafindo Persada, 2013), 191-192.

2 Muhammad Fu'ad 'Abd al-Bāqi, Al-Mu'jam al-Mufahras li Alfāz al-Qur'an al-Karim. Kairo: Dār al-Kutub al-Mișriyyah, 1364, 12, 262.
} 
bodoh, tetapi tak satupun orang yang terdidik perduli mendukung mereka."” "AlQur'an adalah pedoman umat Islam dengan wahyu pertama 'bacalah' namun herannya kaum sufi justru memandang lebih penting zikir".

Kritik ini merupakan cambuk bagi kaum sufi yang kurang mempertimbangkan pentingnya membaca dan menulis sesuai dengan perintah pertama al-Qur'an. Berdzikir juga tidak kalah penting, akan tetapi aspek manfaat yang didapat dari dzikir cakupannya dapat dikatakan sempit. Jika boleh berasumsi, kaum Sufi hanya memikirkan diri sendiri, yang penting saya dekat dengan Tuhan, masalah yang lain terserah. Hal ini tentu berbeda dengan 'dzikir membaca dan menulis'. Jika kedua hal ini digiatkan oleh umat Islam, bukan tidak mungkin umat Islam akan menguasi kembali dunia yang pernah jaya dimasa lalu.

Penulis tidak menafikan bahwa begitu banyak ayat-ayat alQur'an yang memerintahkan untuk beribadah atau mementingkan akhirat. Namun juga jangan dilupakan ayat-ayat lain yang tidak boleh mengesampingkan urusan dunia. Allah berfirman di dalam surah alQașaṣ [28] 77:
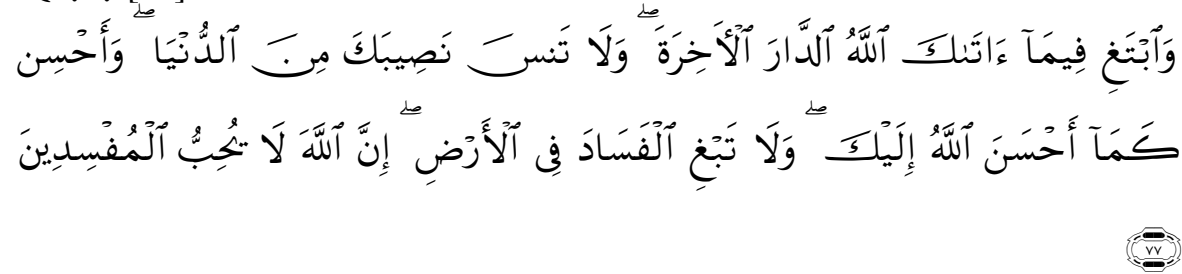

Carilah pada apa yang telah dianugerahkan Allah kepadamu (kebahagiaan) negeri akhirat, dan janganlah kamu melupakan bagianmu dari (kenikmatan) duniawi dan berbuat baiklah (kepada orang lain) sebagaimana Allah telah berbuat baik, kepadamu, dan janganlah kamu berbuat kerusakan di (muka) bumi. Sesungguhnya Allah tidak menyukai orang-orang yang berbuat kerusakan.

Di dalam ayat lain Allah juga menjelaskan tentang psikologis manusia yang sebenarnya butuh dunia. Bukankah kita ketika berdoa

${ }^{3}$ Julia Day Howell dan Martin van Bruinessen, Sufisme dan Modern dalam Islam, dalam Urban Sufism. Jakarta: PT Raja Grafindo Persada, 2008, 9. 
menggunakan ayat rabbana àtinā fi al-dunya hasanah wa fī al-äkbirah hasanah (Wahai Tuhan kami, berikanlah kami kebaikan dunia dan akhirat). Dalam konteks ini kata dunyā diutamakan karena disebutkan lebih dulu, sedangkan kata akhi>rah diakhirkan. Dalam kaidah muqaddammu'akbkhar, kata yang disebutkan lebih dahulu itu adakalanya prioritas, lebih utama, atau memiliki kelebihan yang lain. Beberapa ayat di atas seakan-akan memberikan pesan bahwa seseorang tidak boleh meremehkan urusan duniawiyah. Apalagi urusan itu menyangkut hidup banyak orang. Dalam arti, jika seseorang hanya fokus kepada kehidupannya sendiri (berdzikir, shalat, puasa dan sebagainya), sedangkan dia kurang memperhatikan lingkungannya (tetangganya lapar misalnya), bukankah itu juga suatu kecacatan. Nabi bersabda:

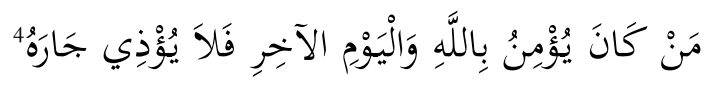

Barang siapa yang beriman kepada Allah dan hari akhir, maka jangan menyakiti tetangganya.

Dalam riwayat lain menyatakan bahwa 'muliakanlah tetangga'. Beberapa pesan dari al-Qur'an maupun hadis ini tampaknya cukup relevan untuk dikatakan bahwa mendekatkan diri kepada Allah itu memiliki banyak cara. Bukan semata-mata dengan berdzikir atau shalat. Dengan memperhatikan itu berarti juga merupakan kebajikan. Salah satu poin penting yang tidak boleh dikesampingkan adalah kbayr al-nās anfa' li al-nās (sebaik-baik manusia adalah yang bermanfaat bagi sesama). ${ }^{5}$

Salah satu kunci untuk memajukan umat Islam adalah dengan kembali kepada perintah pertama al-Qur'an yang menekankan baca tulis. Bukankah umat Islam Jawa seringkali pujian ${ }^{6}$ agami Islam agami

${ }^{4}$ Muḥammad bin Ismā̄il bin Ibrāhim bin al-Mughïrah al-Bukhāri, al-jāmi' al-Ṣaḥịh. Kairo: Dār al-Shu'ab, 1987, vol. 7, 34.

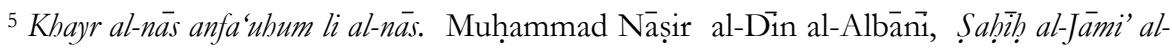
Saghir wa Ziyàdatih. Beirut: al-Maktab al-Islāmi, 1988, vol. 1, 623.

${ }^{6}$ Pujian adalah rangkaian dzikir atau kalimat tayyibat yang dilantunkan setelah adzan hingga iqamat. Pujian ini biasanya menggunakan pengeras suara untuk menanti sang 
kulo, nabi Muhammad nabi kulo, kitab al-Qur'an panutan kula (agama Islam agama saya, nabi Muḥammad nabi saya, kitab al-Qur'an pedoman saya). Meskipun demikian, mengapa umat Islam enggan melaksanakan perintah pertama al-Qur'an dan memilih perintah yang lainnya?

\section{Tarekat Baca-Tulis}

Seperti yang telah penulis singgung di dalam pendahuluan di atas, bahwa tujuan dari seorang sufi adalah mendekatkan diri kepada Allah. Untuk tujuan itu, mereka rata-rata menggamalkan dzikir agar dekat kepada Allah. Sedangkan perintah Allah pertama kali bukanlah dzikir atau shalat, akan tetapi 'membaca'. Jika ingin mendekatkan diri kepada Allah, terlebih dahulu yang diprioritaskan adalah perintahnya yang pertama, yaitu membaca. Allah berfirman di dalam surah al-'Alaq 96:1-5:



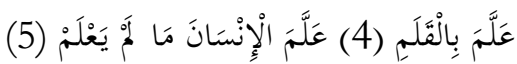

Bacalah dengan menyebut nama Tuhanmu yang menciptakan. Dia menciptakan manusia dari alaq. Bacalah, dan nama Tuhanmu Yang Maba Mulia. Yang mengajarkan manusia dengan pena. Dia mengajarkan manusia apa yang tidak, mereka ketabui. (QS. Al-'Alaq [96]: 1-5).

Istilah tarekat tertua mungkin masih asing di telinga para pengkaji dunia tasawuf, apalagi dengan tarekat 'membaca.' Istilah ini sengaja penulis publikasikan sebab ada beberapa pertimbangan urgen mengenai kemajuan umat Islam. Sering kali umat Islam mengatakan bahwa 'kita harus bangkit' mengingat keterbelakangan umat Islam dibandingkan dengan Barat. Akan tetapi tidak ada kiat khusus dalam merealisasikan cita-cita tersebut sehingga terkesan hanya sebagai jargon saja. Untuk itu, penulis mengedepankan poin ini agar umat Islam bukan hanya

imam shalat sekaligus untuk menarik perhatian jamaah agar shalat berjamaah ke masjid atau mushala. 
Spiritualis, vol. 4, no. 2, September 2018|216

memiliki spiritualitas yang kuat, namun juga pengetahuan yang luas.

Istilah tarekat mungkin yang terkenal adalah Qadiriyah, Naqsabandiyah, Syadziliyah dan sebagainya. Semuanya memiliki amalan yang berlandaskan dari al-Qur'an maupun sunnah Nabi. Akan tetapi substansi tarekat tertua dalam Islam sesungguhnya adalah 'tarekat membaca.' Dalam al-Qur'an terdapat 6.236.' Sementara dari kesekian banyak ayat-ayat tersebut yang pertama kali turun adalah perintah membaca, bukan dzikir, zakat, haji dan sebagainya. Untuk itu, jika di lihat dari segi pereodesasinya, tarekat ini adalah yang tertua dan pendirinya adalah murni Nabi sendiri serta langsung melalui perintah Tuhan.

Jika seseorang mengatakan sebagai seorang muslim, sebaiknya perintah pertama yang hendak di jalankan adalah rajin membaca. Bagaimana tidak, sebab membaca adalah perintah pertama, tidak ada kata lain, bentuknya langsung fi'il amar (kata perintah) iqra' (bacalah), bahkan seorang yang ummi sekalipun ada penekanan agar tetap membaca. ${ }^{8}$

7 'Abd al-Raḥmān bin al-Kamāl Jalāl al-Dīn al-Suyūti, al-Itqān fī 'Ulüm al-Qur'àn. alMaktabah al-Shāmilah al-Iṣdār Thāni. juz I dalam bab 'jumlah ayat'. Sebenarnya dalam keterangan al-Suyūṭi banyak terjadi perbedaan pendapat. Namun ada salah satu pendapat yang menyatakan demikian dan penulis menghitung secara manual jumlah ayat dalam al-Qur'an ternyata jumlahnya adalah seperti keterangan di atas.

${ }^{8}$ Dalam sebab turun surat al-'Alaq ayat pertama di sebutkan bahwa Nabi pada saat itu bermunajat di dalam goa dan bertemu dengan malaikat Jibril. Dalam satu kesempatan, Malaikat Jibril mengatakan iqra' (bacalah) lalu Nabi menjawab mā anā bi qäri'in (aku tidak bisa membaca) lalu pundak Nabi di pegang dan di benamkan sambil mengulang lagi perintah tersebut, iqra' dan Nabi tetap saja menjawab má aná biqäri'in (saya tidak bisa membaca). Kejadian ini berulang hingga tiga kali dan pada akhirnya Nabi memahami perintah tersebut bahwa isinya adalah meniru apa yang di ucapkan oleh malaikat Jibril. Muhammad bin Jarīr bin Yazid bin Kathïr bin Ghālib al-Âmuli Abū

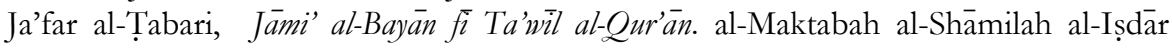
Thāni, QS. Al-'Alaq [96]: 1-5.

Peristiwa ini memberikan indikasi bahwa seorang yang tidak bisa membaca sekalipun masih di tekankan untuk membaca dan jika tidak bisa, maka di tekankan untuk mengulang apa yang di ucapkan oleh seorang guru. Untuk itu, perintah pertama dalam al-Qur'an sesungguhnya menekankan pentingnya membaca. 
Membaca adalah tarekat paling tepat dalam dunia modern. Sebab, dengan mobilitas tinggi dan juga tuntutan zaman yang memaksa umat Islam untuk bangkit tidak lain caranya adalah dengan rajin membaca. Orang yang rajin membaca akan memiliki pengetahuan yang luas dan mampu merubah diri sendiri serta lingkungan agar menjadi lebih baik.

Selain al-Qur'an memerintahkan untuk membaca, manfaat membaca sangat banyak. Dalam sebuah buku yang di tulis oleh Dr. Ngainun Naim, setidaknya ada delapan manfaat membaca. ${ }^{9}$ Pertama, membaca memberikan jawaban atas rasa penasaran dan rasa ingin tahu yang selama ini masih mengganjal dalam benak seseorang.

Pengalaman orang-orang yang terkemuka dapat kita ketahui dengan cara membaca karya orang tersebut. Misalnya Imam al-Shāfi'i yang sangat terkenal dalam dunia Islam Indonesia, apakah al-Shāfi'i kala itu berfikir bahwa 'kelak saya akan memiliki banyak fans di Indonesia.' Pasti tidak akan sampai ke situ. Namun mengapa ia bisa sangat terkenal dan banyak fans di Indonesia atau bahkan di dunia? Jawabannya tidak lain adalah karya yang dibaca.

Al-Shāfi'i memiliki kitab induk al- $\overline{U m}$ dan al-Risāalah yang sangat fundament dalam hukum Islam. Untuk itu, cara terbaik supaya mengetahui pemikiran seseorang adalah dengan cara membaca karya orang tersebut, sebab dengan membaca karya orang, maka kita akan menyelam ke dunia baru dan ilmu baru yang dimiliki oleh penulis karya tersebut.

Kedua, adalah meluaskan cakrawala. Poin ini lebih luas daripada sebelumnya, yaitu ilmu yang di dapat bukan hanya sebatas dari buku yang di baca, tetapi lebih dari itu, yaitu apapun yang dapat di baca akan memberikan pengetahuan baru, karena dokumen, buku, kitab, adalah simpanan ilmu pengetahuan dan akumulasi pengalaman manusia sepanjang sejarah.

9 Ngainun Naim, The Power of Reading: Menggali Kekuatan Membaca untuk Melejitkan Potensi Diri. Yogyakarta: Aura Pustaka, 2013, 32. 
Melalui buku, kitab dan dokumen itulah ilmu di wariskan kepada generasi setelahnya. Oleh karena itu al-Qur'an menegaskan bahwasannya 'Allah yang mengajarkan dengan pena, mengajarkan sesuatu yang tidak ia ketahui.' (QS. Al-'Alaq [96]: 4-5). Ungkapan ini sangat tepat karena semua tulisan instrumen utamanya adalah pena. Dengan membaca seseorang akan mendapatkan cakrawala baru dari bahan yang ia baca.

Ketiga, menjadikan diri tumbuh dan berkembang lebih baik. Buku adalah buah karya seseorang yang berpengalaman dalam bidangnya. Kerja keras seorang penulis tersebut tidak akan sia-sia begitu saja. Akan tetapi dengan menuliskan pengalaman hidupnya yang berharga, dapat di jadikan pelajaran bagi orang lain. Orang yang cepat puas dengan apa yang di dapatkan tanpa harus menggali kembali potensi diri yang ada pada dirinya, tidak menutup kemungkinan di suatu hari ia akan tergeser oleh pendatang baru yang memiliki pengalaman lebih baik. Oleh sebab itu, dengan membaca, kita akan selalu up date pengetahuan menjadi lebih baik lagi dan siap untuk mengembangkan potensi diri menjadi lebih baik pula.

Keempat, menurut para pakar, membaca menguntungkan bagi otak. Hal ini dirasa wajar karena membaca membutuhkan pikiran dan imajinasi. Membaca dapat merangsang kedua belah otak dan juga sistem limbik. Membaca dapat merangsang tumbuhnya neuron (sel saraf otak). Neuron ini tumbuh perlahan-lahan seiring dengan perkembangan manusia, dengan cara meraih neuron lain yang memiliki ranting dendrit (cabang-cabang terjauh neuron) yang sama.

Kelima, membaca dapat merubah paradigma. Paradigma secara sederhana dapat di maknai sebagai cara pandang manusia terhadap suatu hal. Paradigma diilustrasikan seperti kacamata yang akan menentukan penglihatan seseorang terhadap suatu objek. Suatu contoh, jika ada seseorang memiliki paradigma benar-salah, maka dalam hidupnya hanya akan ada dua hal tersebut. 'saya benar, anda salah.' Jika dalam pandangan 
hidupnya hanya satu poin yang benar, maka ia akan menafikan kebenaran yang lain.

Sebuah contoh sederhana terjadi pada masyarakat kita bahkan individu dari masyarakat tersebut. Misalnya dengan kacamata 'bid'ab' seseorang dengan mudah mengatakan kepada orang tertentu atau kelompok tertentu dengan memberikan label tersebut. Dengan rajin membaca, orang kemudian akan tahu di mana letak argumentasi seseorang yang melakukan suatu hal yang awalnya di anggap bid'ah atau citra negatif yang lain.

Misalnya ada seseorang yang mengerjakan shalat berjamaah dengan imam yang tidak membaca basmalah dengan keras. Jika yang ada di dalam benak makmum hanya berbekal pada satu kitab saja, maka ia akan memiliki paradigma yang keras, bahwa hal itu tidak dapat dibenarkan. Namun, jika ia memiliki pengetahuan yang luas, hal itu tidak menjadi persoalan yang serius.

Kika seseorang tahu bahwa hadis tentang basmalah sama-sama berstatus sahih, maka dalam kaidah ulum al-hadith dijelaskan bahwasannya keduanya di jam'u (dikompromikan). Kaidah jam'u memiliki arti, jika seseorang mengambil salah satunya, diperbolehkan. Untuk itu, dengan bekal bacaan yang banyak, seseorang akan berfikir dan bertindak secara proporsional dan lebih lunak tidak gampang untuk menuduh orang lain kafir, bid'ah ataupun salah.

Keenam, dapat mengembangkan kreatifitas. Suatu contoh sederhana adalah pengalaman pribadi penulis. Pada saat penulis membaca buku-buku yang terkesan memojokkan alQur'an dengan mengkritisi dogma yang ada di dalamnya, penulis terpanggil untuk meluruskan kembali salah paham yang di asumsikan oleh sebagian orang.

Kesalah-pahaman itu misalnya, poligami mengapa diperbolehkan bagi pria? Kenapa wanita tidak? Mengapa jika perempuan cerai ada masa iddah sedangkan laki-laki tidak? Mengapa para wanita hanya mendapatkan setengah dari bagian warisan laki-laki? Mengapa dalam persaksian wanita hanya 
separuh kekuatan laki-laki? Kesalah-pahaman ini akhirnya menumbuhkan kreativitas penulis untuk menuliskan judul buku baru yang meluruskan asumsi tersebut.

Ketujuh, menguatkan kepribadian. Diakui atau tidak, buku memiliki pengaruh yang tidak sedikit dalam kehidupan manusia. Misalnya pada saat ia belajar di bangku sekolah dasar, maka ilmu dan pengalaman hidup dia hanya sebatas itu-itu saja. Hal ini berbeda tentunya dengan orang yang telah mengenyam bangku kuliah. Sedikit banyak akan tampak dalam kehidupan sehari-hari, sebab jika ia di bangku sekolah dasar hanya di ajarkan praktik beribadah, maka di jenjang selanjutnya ia akan di ajarkan apa yang wajib dan apa yang tidak wajib dalam beribadah. Setelah itu, ia akan mendapatkan kembali pengetahuan tersebut melalui buku atau kitab secara langsung.

Dengan demikian, akan mengetahui suatu perkara bukan hanya sebatas praktik, tetapi juga mengetahui sumber pengetahuan tersebut. Jika bernasib baik, seseorang bisa menjadi dosen atau guru yang menuntut untuk lebih kuat lagi dalam menguasai ilmu. Jika di bangku sekolah ia sebagai murid, maka tanggung jawabnya hanya sebatas mengikuti pelajaran dan paham terhadap pelajaran yang ada. Namun, jika ia menjadi dosen atau guru, tanggungjawab itu akan berubah. Sebab, ia bukan hanya dituntut untuk 'memahami' sebuah pelajaran, lebih dari itu ia di tuntut untuk 'memahamkan' pelajaran itu kepada yang lain. Beban yang berbeda inilah yang mampu memicu seseorang untuk lebih giat membaca sehingga ia akan menemukan pengalaman baru dan menancapkan ilmunya lebih kuat sehingga menciptakan kepribadian yang lebih baik.

Kedelapan, memberikan perbandingan pengetahuan. Jika seseorang hanya membaca satu buku, maka ia tidak akan menemukan perbedaan dengan buku yang lain. Padahal, antara satu buku dengan buku yang lain saling melengkapi. Baik dalam hal menudukung atau justru memberikan keterangan tambahan yang berbeda. Untuk itu, dengan membaca lebih dari satu buku 
dengan topik yang sama akan memberikan pemahaman yang dalam.

Saat ini manusia dengan mudah dapat mengakses berita melalui internet. Kapan saja dan di mana saja. Jika seseorang ingin mengetahui orang-orang yang sukses yang berbekal dari membaca, maka ia dengan mudah mengakses internet untuk mencarinya. Dalam pandangan penulis, orang-orang sukses atau orang-orang besar, dapat dikatakan bahwa mereka adalah orangorang yang rajin membaca dan menulis. Misalnya Thomas Alfa Edison yang tidak lulus SD mampu memberikan sumbangsih yang sangat besar terhadap perkembangan ilmu pengetahuan. Sebab ia adalah penemu telegraf, bioskop, piringan hitam tabung,. lampu pijar, baterai alkaline, mesin perekam suara, pembangkit listrik dan lain-lain.

Pembangunan pembangkit listrik pertama kali terjadi pada tahun 1882. Orang mungkin tidak banyak yang tahu bahwa sebenarnya Thomas Alfa Edison, tidak lulus SD hanya 3 tahun sekolah SD, bahkan pada usia 12 tahun ia berprofesi sebagai penjual koran di atas kereta api (1877). Jika seorang lulusan SD saja mampu menorehkan presatasi, mengapa kita tidak? Apa yang menyebabkan kita tidak bisa menorehkan prestasi? Kurang bacaan! Sebab Thomas adalah orang yang kirtis terhadap pertanyaan-pertanyaan di sekolah dan bahkan karena kekritisan pertanyaan tersebut ia kemudian diusir oleh gurunya sehingga ia dikeluarkan dan pada akhirnya ia belajar melalui cara otodidak. ${ }^{10}$

Dalam bidang tafsir juga tercatat ada nama Hamka (Haji Abdul Malik Karim Amrullah), yaitu penulis Tafsir al-Azhar sebanyak 15 jilid tebal. Pertanyaannya adalah apakah Hamka saat itu kuliah dan mengambil jurusan tafsir? Tidak! Namun ia mampu menorehkan prestasi itu karena ia rajin membaca dan menulis, bahkan prestasi Hamka dibuktikan dalam karirnya

${ }_{10}$ Ngainun Naim, The Power of Reading: Menggali Kekuatan Membaca untuk Melejitkan Potensi Diri. Yogyakarta: Aura Pustaka, 2013, 160. 
sebagai Ketua Muhammadiyah. Selain Hamka dalam dunia tafsir juga tercatat nama Hasbie al-Siddieqi. Ia adalah penulis Tafsir alQur'an al-Karim. Hasbie ternyata tidak berbeda jauh dengan Hamka, sebab dari segi pendidikan, ia hanyalah tamatan sekolah selevel Mts (Madrasah Tsanawiyah). ${ }^{11}$ Untuk itu, yang harus di gali dari pengalaman orang-orang penting seperti ini bukanlah dari segi pendidikannya, tapi dari semangatnya membaca dan menulis.

Kemajuan Islam masa lalu adalah budaya literasi. Umat Islam seringkali bangga terhadap apa yang telah dicapai masa lalu. Khususnya masa-masa keemasan, yaitu pada masa Abasiyah. Namun kejayaan itu hanyalah cerita masa lalu yang tidak kunjung datang pada masa sekarang. Sebagai generasi penerus kita tidak perlu untuk membanggakan diri terhadap masa lalu, sebab kejayaan itu sudah dimiliki oleh orang-orang pada masanya, bukan kita.

Sedangkan kita hidup dimasa sekarang, masa modern yang jauh ketinggalan dari barat. Baik kejayaan Islam masa lalu maupun kemajuan Barat saat ini, keduanya ternyata memiliki kesamaan. Kesamaannya adalah mereka rajin membaca, melakukan penelitian, penulisan, dan penterjemahan, bukan sekedar berdzikir.

\section{Kesimpulan}

Kesimpulan dari artikel ini adalah jika umat Islam ingin maju dari berbagai hal dan ingin mengulang sejarah masa keemasan peradaban Islam, maka budaya literasi, rajin membaca, kiat dalam belajar, penelitian dan bersifat terbuka terhadap semua ilmu sangat di perlukan. Sebab semua ilmu memiliki manfaat terhadap manusia. Tidak lagi ada dikotomi ilmu dunia dan ilmu agama, tidak lagi ada dikotomi ilmu Islam dan 'ilmu kafir.' Oleh karena itu, jika umat Islam ingin maju dan menguasai dunia, ia juga harus mengamalkan perintah pertama alQur'an, yaitu baca-tulis.

${ }^{11}$ Ibid., 87. 
Spiritualis, vol. 4, no. 2, September $2018 \mid 223$

\section{DAFTAR PUSTAKA}

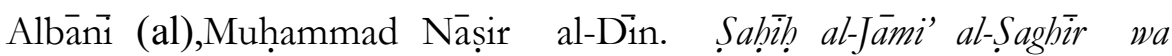
Ziyädatih. Beirut: al-Maktab al-Islāmi, 1988.

Bāqi (al), Muhammad Fu'ad 'Abd. Al-Mu'jam al-Mufahras li Alfã alQur'àn al-Karim. Kairo: Dār al-Kutub al-Mișriyyah, 1364.

Bukhāri (al),Muḥammad bin Ismā̄il bin Ibrāhìm bin al-Mughirah. alJàmi’ al-Saḅị̣. Kairo: Dār al-Shu'ab, 1987.

Howell, Julia Day dan Martin van Bruinessen. Sufisme dan Modern dalam Islam, dalam Urban Sufism. Jakarta: PT Raja Grafindo Persada, 2008.

Naim, Ngainun. The Power of Reading: Menggali Kekuatan Membaca untuk Melejitkan Potensi Diri. Yogyakarta: Aura Pustaka, 2013.

Rusli, Ris'an. Tasawnf dan Tarekat: Studi Perbandingan Pengalaman Sufi. Jakarta: Raja Grafindo Persada, 2013.

Suyūṭi (al), 'Abd al-Raḥmān bin al-Kamāl Jalāl al-Dīn. al-Itqān fī 'Ulum al-Qur'ān. al-Maktabah al-Shāmilah al-Iṣdār Thāni.

Tabari (al),Muhammad bin Jarir bin Yazìd bin Kathïr bin Ghālib alAmuli Abū Ja'far. Jämi' al-Bayān fì Ta'wīl al-Qur'an. al-Maktabah al-Shāmilah al-Ișdār Thāni. 